\title{
Advanced MOODLE Tools in Teaching English for Specific Purposes
}

\author{
N. J. Drozdovych, S. V. Vadaska
}

National Technical University of Ukraine Igor Sikorsky "Politechnic Institute"

Corresponding author. E-mail: drozdovych@gmail.com

Paper received 01.02.19; Accepted for publication 08.02.19.

\author{
https://doi.org/10.31174/SEND-PP2019-188VII77-03
}

\begin{abstract}
The purpose of the study is to demonstrate possibilities of introducing e-learning facility into study of English for special purposes at a technical university based on the own author's experience. Learning management system MOODLE has been chosen as a e-learning platform at National Technical University of Ukraine "Kyiv Polytechnic University". Tools under consideration are different special plugins, esp. "Workshop".
\end{abstract}

Keywords: LMS, MOODLE, Workshop, English for special purposes.

Introduction. An important feature of the modern educational process in higher school is the use of advanced technical means to ensure the interactive nature of learning. Interactivity is particularly attractive in the study of foreign languages, both at the level of everyday communication, and professional or even highly specialized area. It is interesting to note that the first experiences of the application of technical training in combination with the distance education elements, known since the late XIX early XX century, were focused on the study of foreign languages [1]. The use of technical means for education creates a qualitatively new level of perception and immersion in the language environment. The experience of the authors confirms that the attempts to introduce dialogues into the classroom are mostly artificial, and the goal is not reached. They suffer from the limited involvement of two or three participants, while most of the audience is weakly engaged with what is happening. In addition, the organization of a successful dialogue requires the advanced preparation concerning the introduction into the topic, mastering vocabulary, the distribution of the participants' roles. It helps to organize a series of ongoing dialogues as their participants deepen in the subject and topic. Then the question of documenting and properly maintaining a series of conversations following each other arises. Thus, the students get the opportunity to mutually review the materials accompanying the dialogue. The ability to analyze and comment on the performance of others is a requested quality of a future specialist.

Overview of publications on the topic. Analyzing the peculiarity of ESP teaching, it is possible to outline a range of topics that are in contact with the future profession of the student. The paper [2] analyzes the issues in the field of soft skills, considered in the classroom of English with students who study aviation and rocket building. This paper contains an essay on the development of topics for integrating professionally oriented soft skills towards intensifying the interaction of trainees in order to increase their activity and involvement in the learning process. Employment issues for young specialists, including the preparation and assessment of job applications, the organization and conducting of interviews, and some other related issues were chosen as a topic for consideration.

The first question faced by the teacher in organizing electronic and, above all, network support courses is the choice of an e-education platform. Considering the variety of the available systems, the MOODLE platform seems to be the most successful in competition not only among free access systems, but also among proprietary platforms [3]. Choosing MOODLE, you need, of course, first of all to be guided by the range offered by the local computing center, and if necessary, motivate it to install and maintain this particular platform. Although the serious objections connected first of all with information policy of a higher educational institution concerning a set of the means serving all range of information requirements are possible. Reviews of learning management systems contain almost 200 titles, a significant part of which is designed for business, ready to pay substantial amounts monthly or annually, depending on the number of students, courses and/or their course authors. In the academic environment, almost everywhere, preference is given to the MOODLE system, which occupies the first place in many ratings among free access systems in any case [4].

Purpose of the study is to demonstrate advantages of the usage of e-learning systems, esp. MOODLE in ESP teaching at a technical university. The subject of a special study deals with the advanced MOODLE features namely Workshop.

Materials and methods. Using the MOODLE system allows teachers to conduct business games, introduce assessment and self-assessment elements, accumulate evaluation points, control the systematic nature of the students activities, and support an effective organization of feedback. It also seems important that all these opportunities remain available to students and outside the classroom, ensuring their own pace of studying the material, depending on the training level and the interests of the students. Moreover, forum existence allows teachers to organize the round-the-clock communication of students among themselves and with the teacher. The teacher has the opportunity to receive complete information about the activity of the student for the entire period of the course. For this purpose you need to open students' personal cards. It is also possible for the to ask for the additional information, for example, a report on the students' attendance of course materials:

\section{Peter Peterson}

Activity report

Module 11 viewing Monday September 10 2018, 11:35

Module 21 viewing Thursdays September 202018 , $00: 37$

Module 31 viewing Tuesday September 292018 , $10: 13$ 
Module 41 viewing Friday October 5 2018, 00:42

Module 52 viewings Tuesday 16 October 2018, 00:46

Thursdays 18 October 2018, 14:35

Module 61 viewing Friday 5 грудня 2018, 00:39

Module 71 viewing середа 5 грудня 2018, 09:04

The final assessment of students for the semester including 10 assessed tasks is possible to be provided. Each task is provided with the maximum possible number of points within which it can be evaluated. The teacher can set the dead line for each task and, at its sole discretion, either completely ban the work after the completion of the work, or in case of lateness, respectively, reduce the maximum grade. The accumulated points for the semester can be added to the scores obtained for the exam (test).

It is important that the students participation in each of the activities to be assessed and included in the system of accumulating credits during the semester is completely transparent and available for analysis both by the teacher throughout the group and by each student regarding his/her personal achievements. This is what Student will see on its rating page when logging in using a personal login and password. The course program establishes the limit values of points required for admission to the exam or offset. For example, if this value is set at 30 points, then in order to obtain admission, Student will receive a signal that it is necessary to perform the task 03 or 10 . All the assignments results are in the general storage, the capacity of which is to provide storage of the results of the current semester, and also of several previous years. Thus, it is possible to control academic conscience, for example, by means of plagiarism detection.

An important advantage of the MOODLE system is the presence of numerous plugins focused on various aspects of the learning process. The author experience in using the MOODLE system settings when learning English vocational guidance was outlined in [5]. These settings include the means of organizing the terminology trainer, quests, crosswords, and various types of tests. Their application introduces an element of diversity in the educational process.

All the types of tasks discussed above assume the individual activity of the student. As you know, one of the key qualities of an employee is his ability to work in a team. The simplest way to organize teamwork is to hold forums. Forums can be moderated by the teacher. In this case, the automatic calculation of the results of each student is difficult. However, the teacher can take into account the activity and effectiveness of student participation in the forum within the framework provided by the test or examination grade or even select a separate type of work (assignment) evaluated separately. If the topic of the forum concerns one of the regular tasks, then the mark for participation in it can be accumulated as part of the mark for the corresponding task. However, such type of task as the forum of one participant is of particular importance. In this case each student can create a single forum and become its moderator inviting all members of the academic group to participate in it. Such a form of learning activities like one-to-many allows teachers to organize a discussion of the issue, conduct a case study, organize certain types of business games, collaborate on a project, etc. The moderator receives an assessment depending on the skills, initiative and competence in organizing the discus- sion, motivating the participants, provoking them to a certain extent.

The next step in the development of teamwork by means of the MOODLE system consists in a more precise definition of teams and the distribution of the roles of their participants. For this purpose, in particular, the MOODLE system has an educational resource Workshop. According to the author of the work [6], the name of the resource does not reflect its purpose. The author [4], like other authors (see, for example, [7] - [10]), considers that the Workshop resource serves as a means of organizing peer-to-peer interaction of students, including on a large scale, allowing everyone to perform both peer-reviewing and self-reviewing.

Results and discussion. Of course, the organization and implementation of the Workshop require some effort from the teacher. First of all, it is necessary to accurately determine its topic and clearly formulate the task. Proceeding from the problems of soft skills, the topic can be chosen considering the tasks of employment, scholarship or scholarships. Now the teacher must configure Workshop. If we dwell on the problem of employment, then the configuration may consist in preparing and placing on the server a hypothetical announcement about inviting employees with a certain qualification to work. We define the stages, roles and tasks. At the first stage, all participants act as job seekers. They submit cover letters, personal summaries and possibly other supporting documents.

At the second stage, the students act as the employees of an employment agency evaluating job applications filed. If the advertisement indicates several vacancies and/or several different vacancies, the recruiter selects the best, in his opinion, applications and transfers them to further consideration. All applications are rated by the recruiter in accordance with the criteria specified by the teacher. The first stage of the review, therefore, is to review the applications. The quality of the cover letter is evaluated. In addition to the actual content, the author's style is assessed in terms of its correspondence to the accepted style of business documents, the design and formatting of the document. Special attention is paid to resume evaluation. It is important to correctly formulate the objectives of the applicant, his education, previous experience and achievements.

Now every student will play the role of a human resource officer reviewing recruiters' proposals. Their opinions on the quality of job applications submitted are reviewed, which are also recorded on the site. A student in the role of a human resource officer prepares proposals for a professional leader who makes the final decision. In this role, it is logical to speak to the teacher, who will formulate a final assessment of the student's activities in each of the three roles.

As an optional option, self-reviewing of your own job application is possible as a student's response to the conclusions of both a human resource officer and recruiters. In any case, the use of the Workshop resource introduces a significant element of diversity in the educational process and, moreover, helps students in preparing for the vital type of their future activity - the employment process. The English course for specific purposes is the most suitable place for such training, since in the context of 
globalization; English is the most likely language of professional communication.

Conclusion. Hence, such peer review encourages more responsible performance of the work, allow teacher to see its strengths and weaknesses, compare the work with others and identify ways to improve it.

At first students are wary of this type of reviewing because of fear of unfair assessment. However, practice shows that they are able to fairly objectively evaluate the work, if they have sufficiently clear criteria that exclude excessive subjectivity. As a rule, in evaluating each other, students may be even pickier than the teacher himself.

In any case, the use of e-education systems in the conditions of stationary education will certainly improve the quality of both the educational process itself and the level of results achieved.

\section{ЛИТЕРАТУРА}

1. Бублик В.В.Шляхами дистанційної освіти та електронного навчання/В.В. Бублик // Наукові записки НаУКМА.2018. - Т.1:Комп'ютерні науки. - С. 4-9.

2. Дроздович Н.Ю. Enhencing students' soft skill abilities through english for specific purposes/H.Ю. Дроздович//Вісник Національного технічного університету України «Київський політехнічний інститут». Серія: Філологія. Педагогіка Київ, 2016. - №7. - С.26-30

3. LMS Software. Capterra. [electronic resource]-Access mode: https://www.capterra.com/learning-management-systemsoftware/

4. Henry Kronk, 2018 IN REVIEW: LEARNING MANAGEMENT SYSTEMS,/ Henry Kronk Elearning Inside, December 12, 2018, [electronic resource].-Access mode: https://news.elearninginside.com/2018-in-reviewlearning-management-systems/

5. Вадаська С.В. ESP materials for aeronautical students/C.B. Вадаська// Вісник Національного технічного університету України «Київський політехнічний інститут». Серія: Філологія. Педагогіка: Зб. н. праць. - Київ, 2016. - №7. C. $16-20$

6. Пасічник О.В. Семінар як інструмент взаємного оцінювання у дистанційному курсі, НВК "Школа-гімназія "Сихівська"/ Пасічник О.B. [electronic resource].-Access mode: http://DystOsvita.MDL2.com/

7. Add a Workshop Activity in Moodle, UMass Amherst Information Technology [electronic resource].-Access mode: (https://www.umass.edu/it)

8. Assessment settings for Workshops in Moodle, UMass Amherst Information Technology [electronic resource].-Access mode: (https://www.umass.edu/it)

9. Irena Reimannová, Moodle Workshop Module in Project Paper Writing,/ Irena Reimannová// Conference UNICOM June 2014, Pardubice, Czech Republic

10. Dr. Karin Richter, Gabrielle Smith-Dluha, How can peer editing improve student writing? Using the Moodle Workshop tool in the tertiary ESL classroom, 9th Austrian UAS Language Instructors' Conference English for Specific Purposes: A Multidimensional Challenge / Dr. Karin Richter, Gabrielle Smith-Dluha // Wien, 25 - 26 May 2018, P.54-72.

\section{REFERENCES}

1. Boublik V.V. On the road to distance education and elearning/V.V. Бублик // NaUkma Rsearch Papers._ 2018. V.1:Computer Science. - p. 4-9..

2. Drozdovych N.J. Enhencing students' soft skill abilities through english for specific purposes/ N.J. Drozdovych //Journal of the National Technical University of Ukraine " Kyiv Polytechnic Institute». Philology and Educational Studies, 2016, Issue 7. - P.26-30

3. LMS Software. Capterra. [electronic resource].-Access mode: https://www.capterra.com/learning-management-systemsoftware/

4. Henry Kronk, 2018 IN REVIEW: LEARNING MANAGEMENT SYSTEMS,/ Henry Kronk Elearning Inside, December 12, 2018, [electronic resource].-Access mode: https://news.elearninginside.com/2018-in-reviewlearning-management-systems/

5. Vadaskaya S.V. ESP materials for aeronautical students/ S.V. Vadaskaya // Journal of the National Technical University of Ukraine « Kyiv Polytechnic Institute». Philology and Educational Studies, 2016, Issue 7. - P.16-20

6. Pasichnyk O.V. Seminar as a tool for mutual evaluation in a distance course, NSC "School-gymnasium" Sykhivska "/ Pasichnyk O.V. [electronic resource].-Access mode: http://DystOsvita.MDL2.com/

7. Add a Workshop Activity in Moodle, UMass Amherst Information Technology [electronic resource].-Access mode: (https://www.umass.edu/it)

8. Assessment settings for Workshops in Moodle, UMass Amherst Information Technology [electronic resource].-Access mode: (https://www.umass.edu/it)

9. Irena Reimannová, Moodle Workshop Module in Project Paper Writing,/ Irena Reimannová// Conference UNICOM June 2014, Pardubice, Czech Republic

10. Dr. Karin Richter, Gabrielle Smith-Dluha, How can peer editing improve student writing? Using the Moodle Workshop tool in the tertiary ESL classroom, 9th Austrian UAS Language Instructors' Conference English for Specific Purposes: A Multidimensional Challenge / Dr. Karin Richter, Gabrielle Smith-Dluha //Wien, 25 - 26 May 2018, P.54-72. 